\title{
Identifikasi Stabilitas Hasil Genotipe Ubi Jalar (Ipomoea batatas L. (Lam)) Harapan Baru di Tiga Lingkungan
}

\section{Identification of Yield Stability on New Promising Sweet Potatoes (Ipomoea batatas L. (Lam)) Genotypes in Three Environments}

\author{
Agung Karuniawan ${ }^{1,2, *}$ dan Haris Maulana ${ }^{1}$ \\ ${ }^{1}$ Jurusan Budidaya Pertanian, Fakultas Pertanian, Universitas Padjadjaran \\ Jl. Raya Bandung-Sumedang Km 21, Kampus Jatinangor, Kabupaten Sumedang, Jawa Barat, 45363, Indonesia \\ ${ }^{2}$ Magister Manajemen Sumberdaya Hayati, Sekolah Pascasarjana, Universitas Padjadjaran \\ Jl. Dipati Ukur No. 35, Bandung, 40132, Indonesia
}

Diterima 13 Oktober 2020/Disetujui 2 Desember 2020

\begin{abstract}
Multilocation tested is needed to estimate the yield stability of the tested plants. This study aimed to estimate the genotype by environment interactions (GxE), identify the yield stability of the new promising sweet potato genotypes, and identify static and dynamic stability measurement models for sweet potato yields. The research was conducted in three environments in West Java, i.e., Sumedang Regency (729 masl), Bandung Regency (857 masl), and Karawang Regency (24 masl) from January 2017 to July 2018. The field experiment used an augmented design at each location. To estimate the GxE, a combined analysis of variance (ANOVA) was used, while the yield stability was estimated using the parametric (linear regression (bi and $\left.S^{2} d i\right)$, mean variance component $(\theta i)$, genotypes variance environments $(G E)\left(\theta_{(i)}\right)$, Wricke ecovalence $\left(\right.$ Wi $\left.{ }^{2}\right)$, Shukla variance stability $\left(\sigma^{2} i\right)$, coefficient of variation (CVi), AMMI stability value $\left.(A S V)\right)$ and non-parametric stability measurements (Huehn (Si), Thennarasu (NP(i)), Kang Ranks (KR)), and GGE biplot. The results showed that GxE had a significant effect on the yield with a contribution of $14.17 \%$. Two new sweet potato genotypes were identified as stable and high yields in three environments, they were PR79 and PR126. These genotypes can be recommended as new superior genotypes and as materials for further sweet potato plant breeding programs. $N P^{(2)}$ and $\theta_{i}$ stability measurements were the static stability models that can recommend the stable genotypes in unfavorable environments, while $S^{(1)} S^{(2)}, S^{(3)}, S^{(6)}, N P^{(1)}$, $N P^{(3)}, N P^{(4)}, K R, C V i, b i, S^{2} d i, W i^{2}, A S V$, and $\sigma^{2}$ were the dynamic stability models that can recommend the stable genotypes in favorable environments.
\end{abstract}

Keywords: GGE biplot, multilocation, non-parametric, parametric, yield stability

\section{ABSTRAK}

Pengujian multilokasi diperlukan untuk mengestimasi stabilitas hasil dari tanaman yang diuji. Penelitian ini bertujuan untuk mengestimasi interaksi genotipe dengan lingkungan (GxE), mengidentifikasi stabilitas hasil genotipe-genotipe baru ubi jalar, serta mengidentifikasi pengukuran stabilitas yang statis dan dinamis terhadap hasil ubi jalar. Penelitian dilakukan di tiga lingkungan di Jawa Barat, diantaranya pada dataran medium yaitu Kabupaten Sumedang (729 mdpl), Kabupaten Bandung (857 mdpl), serta pada dataran rendah yaitu Kabupaten Karawang (24 mdpl) dari bulan Januari 2017-Juli 2018. Percobaan menggunakan rancangan lapangan Augmented design di setiap lokasi. Analisis ragam (ANOVA) gabungan digunakan untuk mengestimasi GxE, sedangkan stabilitas hasil diestimasi dengan pengukuran model stabilitas parametrik (Regresi linier Eberhart dan Russell (bi dan $\left.S^{2} d i\right)$, komponen rata-rata varians $(\theta i)$, varians genotipe terhadap lingkungan $(G E)\left(\theta_{(i)}\right)$, Wricke ecovalence $\left(W i^{2}\right)$, varians stabilitas Shukla $\left(\sigma^{2} i\right)$, koefisien variasi (CVi), AMMI stability value (ASV)), non-parametrik (model Huehn ( $\left.S^{(i)}\right)$, model Thennarasu (NP(i)), Peringkat Kang (KR)), dan GGE biplot. Hasil penelitian menunjukkan bahwa GxE menunjukkan pengaruh yang signifikan terhadap hasil panen dengan kontribusi sebesar $14.17 \%$. Dua genotipe ubi jalar teridentifikasi stabil dan memiliki hasil tinggi di tiga lingkungan yaitu PR79 dan PR126. Genotipe-genotipe tersebut dapat direkomendasikan sebagai genotipe unggul baru dan sebagai bahan untuk program pemuliaan tanaman ubi jalar selanjutnya. Pengukuran stabilitas $N P^{(2)}$ dan $\theta_{i}$ merupakan model stabilitas statis yang dapat merekomendasikan genotipe stabil pada lingkungan yang kurang menguntungkan (unfavorable), sedangkan pengukuran $S^{(1)}, S^{(2)}, S^{(3)}, S^{(6)}, N P^{(1)}, N P^{(3)}$, $N P^{(4)}, K R, C V i, b i, S^{2} d i, W i^{2}, A S V$, dan $\sigma_{i}^{2}$ merupakan model stabilitas dinamis yang dapat merekomendasikan genotipe stabil pada lingkungan yang menguntungkan (favorable).

Kata kunci: GGE biplot, multilokasi, non-parametrik, parametrik, stabilitas hasil

\footnotetext{
* Penulis untuk korespondensi. e-mail: agung.karuniawan@unpad.ac.id
} 


\section{PENDAHULUAN}

Ubi jalar merupakan salah satu komoditas pertanian yang memiliki nilai ekonomi tinggi di Jawa Barat. Beberapa produk olahan yang berasal dari ubi jalar meningkatkan nilai jual dari komoditas ini, diantaranya biofuel (Waluyo et al., 2015), pewarna alami (Hariadi et al., 2018), serta tepung dan snack bar (Sunyoto et al., 2019). Selain itu, industri pangan yang menjadikan ubi jalar sebagai bahan baku utamanya, juga telah banyak berkembang di provinsi Jawa Barat (Maulana et al., 2020). Akan tetapi, jumlah permintaan ubi jalar dari industri dan pasar tidak sejalan dengan kapasitas produksi. Hal ini dikarenakan menurunnya hasil dari varietas yang sesuai preferensi konsumen dan pasar, serta kualitas varietas-varietas yang beredar tidak memenuhi standar (spesifikasi tidak sesuai). Oleh karena itu, diperlukan varietas unggul baru ubi jalar yang sesuai dengan preferensi konsumen dan industri dengan hasil yang tinggi.

Pengujian multilokasi sangat penting dalam program pemuliaan tanaman. Saat ini, program pengembangan genotipe yang stabil dan berdaya hasil tinggi serta sesuai dengan preferensi konsumen, adalah salah satu tujuan utama programpemuliaan ubi jalar(Maulana etal., 2020). Pengujian multilokasi dapat mengetahui genotipe-genotipe stabil pada lingkungan yang luas, serta adaptip pada lingkungan yang spesifik. Efek GxE pada pengujian multilokasi terutama terjadi pada karakter kuantitatif termasuk hasil panen (Andrade et al., 2016a), serta resistensi terhadap faktor biotik dan abiotik (Dia et al., 2016). Saat ini telah banyak penelitian yang menggunakan kombinasi model stabilitas parametrik dan non-parametrik dalam menyeleksi genotipe stabil dan berdaya hasil tinggi, diantaranya pada tanaman buncis (Cicer arietinum L.) (Farshadfar et al., 2012), pada tanaman kacang rumput (Lathyrus sativus L.) (Ahmadi et al., 2015), pada tanaman gandum (Abate et al., 2015), pada tanaman jelai (Khalili dan Pour-aboughadareh, 2016; Vaezi et al., 2019), pada tanaman jagung manis (Ruswandi et al., 2020), dan pada tanaman ubi jalar (Maulana et al., 2020). Pada penelitian lainnya, Ajay et al. (2020) berhasil menyeleksi tanaman kacang pada kondisi cekaman pospor di India dan Sabaghnia et al. (2013) pada tanaman gandum di Iran dengan penggabungan berbagai parameter AMMI. Penggunaan gabungan model stabilitas dikarenakan analisis dengan satu pengukuran stabilitas pada genotipe-genotipe yang diuji dianggap kurang informatif (Khalili dan Pouraboughadareh, 2016). Oleh karena itu, penggabungan berbagai pengukuran stabilitas dalam menyeleksi genotipe yang stabil dan berdaya hasil tinggi pada pengujian multilokasi, lebih dianjurkan.

Saat ini Universitas Padjadjaran (UNPAD), telah memiliki genotipe baru ubi jalar hasil persilangan terarah. Kegiatan ini merupakan kerjasama antara UNPAD dengan CIP Peru. Tujuan penelitian ini adalah untuk mengestimasi pengaruh GxE terhadap hasil panen ubi jalar, menyeleksi genotipe-genotipe ubi jalar baru yang stabil dan berdaya hasil tinggi di Jawa Barat, serta mengidentifikasi pengukuran stabilitas yang statis dan dinamis terhadap hasil ubi jalar di Jawa Barat.

\section{BAHAN DAN METODE}

\section{Bahan Tanam dan Metode}

Bahan tanaman yang digunakan dalam penelitian ini adalah 27 genotipe harapan baru hasil persilangan terarah (Tabel 1) dan tujuh varietas cek sebagai kontrol yaitu Rancing (C1), AC-Putih (C2), Keriting Maja (C3), Ayamurasaki (C4), Beniazuma (C5), Kidal (C6), dan Beta2 (C7). Genotipe-genotipe yang digunakan ini merupakan hasil seleksi sesuai preferensi konsumen berdasarkan Maulana et al. (2016). Pupuk yang digunakan yaitu pupuk kandang (kotoran ayam) dengan dosis 5 ton ha ${ }^{-1}$ dan pupuk NPK Phonska (16:16:16) dengan dosis $200 \mathrm{~kg} \mathrm{ha}^{-1}$.

Percobaan lapangan pada setiap lokasi menggunakan rancangan Augmented design tipe 2. Setiap genotipe yang diuji tidak dilakukan pengulangan dan ditanam pada plot berukuran $5 \mathrm{~m}^{2}$ setiap genotipenya. Hal ini dikarenakan bahan tanam dari setiap genotipe masih terbatas. Percobaan dilakukan di tiga lokasi Jawa Barat, yaitu Kebun Percobaan Ciparanje, Kecamatan Jatinangor, Kabupaten Sumedang

Tabel 1. Daftar genotipe yang diuji

\begin{tabular}{|c|c|c|c|}
\hline No. & Kode genotipe & \multicolumn{2}{|c|}{ Nama genotipe } \\
\hline 1 & PR17 & CIP 102030 & 1.16 \\
\hline 2 & PR20 & CIP 102030 & 1.19 \\
\hline 3 & PR39 & CIP 103002 & 2.60 \\
\hline 4 & PR43 & CIP 103002 & 2.10 \\
\hline 5 & PR53 & CIP 103002 & 2.20 \\
\hline 6 & PR54 & CIP 103002 & 2.21 \\
\hline 7 & PR56 & CIP 103002 & 2.23 \\
\hline 8 & PR79 & CIP 103002 & 2.45 \\
\hline 9 & PR84 & CIP 103002 & 2.50 \\
\hline 10 & PR114 & CIP 103009 & 3.10 \\
\hline 11 & PR115 & CIP 103009 & 3.11 \\
\hline 12 & PR118 & CIP 103009 & 3.13 \\
\hline 13 & PR121 & CIP 103009 & 3.16 \\
\hline 14 & PR125 & CIP 103009 & 3.20 \\
\hline 15 & PR126 & CIP 103009 & 3.21 \\
\hline 16 & PR136 & CIP 103009 & 3.31 \\
\hline 17 & PR144 & CIP 103009 & 3.39 \\
\hline 18 & PR165 & CIP 103017 & 4.11 \\
\hline 19 & PR168 & CIP 103017 & 4.14 \\
\hline 20 & PR174 & CIP 103017 & 4.20 \\
\hline 21 & PR178 & CIP 103017 & 4.24 \\
\hline 22 & PR179 & CIP 103017 & 4.25 \\
\hline 23 & PR191 & CIP 103017 & 4.37 \\
\hline 24 & PR196 & CIP 103017 & 4.42 \\
\hline 25 & PR202 & CIP 103017 & 4.48 \\
\hline 26 & PR235 & CIP 103029 & 5.20 \\
\hline 27 & PR838 & CIP 103033 & 12.67 \\
\hline
\end{tabular}


dengan ketinggian 729 mdpl; Kebun Percobaan Arjasari, Kecamatan Arjasari, Kabupaten Bandung dengan ketinggian 857 mdpl; dan Desa Puseurjaya, Kecamatan Telukjambe, Kabupaten Karawang dengan ketinggian 24 mdpl sejak Januari 2017 hingga Juli 2018. Kondisi lingkungan disetiap lokasi percobaan tersaji pada Tabel 2. Pada rancangan ini ulangan dilakukan hanya pada aksesi kontrol atau cek yaitu sebanyak 3 ulangan. Penggunaan augmented design tipe 2 ini bertujuan untuk mengestimasi variasi lingkungan pada lokasi pengujian. Jarak tanam yang digunakan adalah 100 $\mathrm{cm} \times 25 \mathrm{~cm}$.

Banyaknya blok yang dibutuhkan ditentukan oleh hubungan derajat bebas untuk error pada analisis varians dengan kontrol atau tetua. Jika c adalah jumlah kontrol yang berbeda yang digunakan, dan $\mathrm{r}$ adalah jumlah blok, maka derajat bebas untuk error paling sedikit harus sama dengan 10, seperti yang ditunjukkan pada rumus berikut: (r-1) $(\mathrm{c}-1) \geq 10$.

\section{Analisis Data}

Data diambil dari setiap lokasi dengan mengukur bobot per plot dari setiap genotipe (kg per plot) pada saat panen (18 MST). Estimasi interaksi genotipe dengan lingkungan (GxE) mengikuti You et al. (2013). Pada percobaan lapangan augmented design, analisis varians gabungan dari nilai varietas cek yang disesuaikan dilakukan untuk menguji stabilitas hasil dan sifat lain dari genotipe uji di lingkungan yang berbeda. Karena tidak ada ulangan untuk genotipe uji, kesalahan percobaan (error) gabungan dapat diestimasi berdasarkan nilai yang disesuaikan dari plot kontrol (cek). Heterogenitas tanah dari plot kontrol dihilangkan dengan penyesuaian data, sehingga nilai rc (jumlah nilai yang disesuaikan dari plot kontrol) dapat dianggap sebagai nilai yang direplikasi. Oleh karena itu, ANOVA gabungan varietas cek dari setiap blok berbeda digunakan untuk memperkirakan kesalahan percobaan di berbagai lingkungan. Adapun tabel ANOVA gabungan augmented design tersaji pada Tabel 3. Uji Least Significant Increase (LSI) digunakan untuk mengestimasi performa hasil setiap genotipe yang diuji terhadap varietas cek, mengikuti Petersen (1994).

Identifikasi stabilitas genotipe dilakukan dengan menggunakan penggabungan model stabilitas parametrik dan non-parametrik. Regresi linier dilakukan dengan menggunakan metode Eberhart dan Russell, (1966). Berdasarkan model ini, jika kemiringan regresi (bi) sama dengan 1 dan deviasi varians ( $\left.\mathrm{S}^{2} \mathrm{di}\right)$ sama dengan 0 , maka genotipe dinyatakan stabil. Untuk mengestimasi komponen rata-rata varians $(\theta i)$, mengikuti Plaisted dan Peterson (1959). Komponen varians genotipe terhadap lingkungan (GE) $\left(\theta_{(\mathrm{i})}\right)$ mengikuti Plaisted (1960), Wricke ecovalence $\left(\mathrm{Wi}^{2}\right)$ mengikuti Wricke (1962), varians stabilitas Shukla $\left(\sigma^{2} i\right)$ mengikuti (Shukla, 1972), dan koefisien variasi (CVi) mengikuti Francis dan Kannenberg (1978).

Model stabilitas non-parametrik $\left(\mathrm{S}^{(\mathrm{i})}\right)$ mengikuti Huehn, (1990). Model stabilitas $\left(\mathrm{NP}^{(\mathrm{i})}\right)$ mengikuti Thennarasu (1995), dan model stabilitas non-parametrik Peringkat Kang (KR) mengikuti Kang (1988). Dalam metode ini, performa hasil dan varians stabilitas genotipe dengan hasil tinggi dan stabil diberi bobot 1 .

Pengukuran stabilitas menggunakan AMMI Stability Value (ASV) dihitung dengan formula mengikuti (Purchase et al., 2000). Untuk mengestimasi stabilitas hasil berdasarkan model parametrik dan non-parametrik, digunakan perangkat lunak online STABILITYSOFT (Pour-aboughadareh et al., 2019). Pengelompokkan genotip stabil berdasarkan pengukuran stabilitas parametrik dan non-parametrik

Tabel 2. Kondisi lingkungan pada tiga lokasi pengujian

\begin{tabular}{|c|c|c|c|}
\hline Lingkungan & Kabupaten Sumedang & Kabupaten Bandung & Kabupaten Karawang \\
\hline Ketinggian (m.dpl) & 729 & 857 & 24 \\
\hline Koordinat & $6^{\circ} 55^{\prime} 00.6 ” S$ 10746'18.3”E & $7^{\circ} 03$ '35.3”S 107³8'46.5”E & $6^{\circ} 20^{\prime} 15.1$ 'S $107^{\circ} 18^{\prime} 20.2$ 'Е \\
\hline Jenis Tanah & Inceptisols & Inceptisols & Inceptisols \\
\hline \multicolumn{4}{|c|}{ Curah hujan (mm/bln): } \\
\hline Minimum & 119.10 & 124.00 & 119.20 \\
\hline Maksimum & 874.30 & 367.00 & 287.30 \\
\hline Rata-rata & 538.00 & 198.20 & 175.32 \\
\hline \multicolumn{4}{|l|}{ Suhu udara $\left({ }^{\circ} \mathrm{C}\right)$ : } \\
\hline Minimum & 22.50 & 24.00 & 23.00 \\
\hline Maksimum & 23.10 & 29.00 & 31.10 \\
\hline Rata-rata & 22.86 & 26.00 & 26.52 \\
\hline $\mathrm{pH}$ & 7.28 & 6.85 & 7.70 \\
\hline $\mathrm{K}$ & 0.37 & 0.69 & 0.30 \\
\hline $\mathrm{P}$ & 26.68 & 45.49 & 17.77 \\
\hline $\mathrm{N}$ & 0.18 & 0.21 & 0.13 \\
\hline C-Organik & 1.70 & 2.17 & 1.33 \\
\hline
\end{tabular}


Tabel 3. Analisis varians (ANOVA) gabungan augmented design pada varietas cek

\begin{tabular}{llll}
\hline Sumber variasi & \multicolumn{1}{c}{$\mathrm{DB}$} & $\mathrm{KT}$ & $\mathrm{Uji \textrm {F }}$ \\
\hline Genotipe $(\mathrm{G})$ & $g-1$ & $\mathrm{KT} g$ & $\mathrm{KT} / \mathrm{KT}_{\mathrm{E}}$ \\
Lingkungan $(\mathrm{E})$ & $e-1$ & $\mathrm{KT} e$ & $\mathrm{KT} / \mathrm{KT}_{\mathrm{E}}$ \\
Interaksi Genotipe dengan Lingkungan $(\mathrm{GxE})$ & $(g-1)(e-1)$ & $\mathrm{KT} g e$ & $\mathrm{KT} / \mathrm{KT}_{\mathrm{E}}$ \\
Error & $e((\mathrm{rc}-1)+2(\mathrm{~m}-1))$ & $\mathrm{KT}_{\mathrm{E}}$ & \\
\hline
\end{tabular}

Keterangan: $\mathrm{DB}=$ Derajat Bebas; $\mathrm{KT}=$ Kuadrat Tengah; $\mathrm{g}=$ jumlah varietas cek yang digunakan; $\mathrm{e}=$ jumlah lokasi/lingkungan; $\mathrm{rc}=$ jumlah nilai yang disesuaikan dari plot kontrol, $\mathrm{m}=$ jumlah blok yang digunakan

menggunakan dendrogram berdasarkan peringkat masingmasing pengukuran. Estimasi model stabilitas menggunakan GGE biplot mengikuti Yan dan Tinker (2006). Seleksi genotipe stabil dan berdaya hasil tinggi berdasarkan irisan antara genotipe-genotipe yang terseleksi oleh pengukuran stabilitas parametrik dan non-parametrik, serta GGE biplot. Identifikasi model pengukuran stabilitas statis dan dinamis menggunakan korelasi peringkat Spearman dan principal component analysis (PCA) (Vaezi et al., 2019).

\section{HASIL DAN PEMBAHASAN}

\section{Interaksi Genotipe dengan Lingkungan}

Hasilanalisis varians (ANOVA) gabungan padavarietas cek yang diuji tersaji pada Tabel 4 . Tabel 4 menunjukkan bahwa efek lingkungan memberikan kontribusi terbesar terhadap keragaman hasil panen ubi jalar (74.84\%), diikuti oleh efek interaksi genotipe dengan lingkungan (GxE) (14.17\%), dan efek genotipe (10.99\%). Beberapa peneliti juga melaporkan bahwa GxE mempengaruhi hasil panen ubi jalar (Haldavanekar et al., 2011; Kathabwalika et al., 2013; Mau et al., 2013; Laurie et al., 2015; Gurmu, 2017; Rukundo et al., 2017; Mustamu et al., 2018; Ngailo et al., 2019). Hal ini menunjukkan bahwa variasi hasil panen ubi jalar sangat dipengaruhi oleh faktor lingkungan.

Munculnya efek GxE dengan kontribusi yang cukup besar, menunjukkan bahwa hasil panen ubi jalar bervariasi pada setiap lokasi percobaan. Hal ini membuat program pemuliaan tanaman ubi jalar menjadi kurang efisien (Andrade et al., 2016a). Pada penelitian lainya, GxE juga memberikan pengaruh yang signifikan terhadap hasil panen seperti Purwokurniawan et al. (2014) pada padi gogo di Indonesia,
Oliveira et al. (2014) pada markisa kuning di Brazil, Ngailo et al. (2019) pada ubi jalar di Tanzania, dan Hastini et al. (2020) pada padi sawah di Indonesia. Adanya GxE yang signifikan menyebabkan perlu dilakukannya analisis lanjutan dengan berbagai pendekatan untuk mengestimasi stabilitas hasil (Khalili dan Pour-aboughadareh, 2016; Vaezi et al., 2019; Maulana et al., 2020). Oleh karena itu, berbagai pengukuran stabilitas digunakan untuk mengelompokkan genotipe-genotipe ubi jalar pada kelompok yang lebih jelas.

Nilai koefisien variasi (CV) yang dihasilkan pada penelitian ini sangat besar (45.63\%). Menurut Andrade et al., (2016b), besarnya CV menunjukkan bahwa akurasi data hasil penelitian kurang representastif dan variasi hasil panen dari setiap genotipe di setiap lokasi tanam cukup tinggi. Solihin et al. (2018), juga melaporkan bahwa variasi lingkungan menyebabkan perbedaan potensi dan kualitas hasil ubi jalar. Nilai CV yang dihasilkan pada sebuah percobaan disebabkan oleh berbagai faktor diantaranya lingkungan percobaan, jenis percobaan (rancangan percobaan), tanaman yang diuji, dan karakter yang diamati (Maulana et al., 2018; Prayudha et al., 2019). Pada penelitian ini, besarnya nilai CV yang dihasilkan kemungkinan disebabkan oleh desain percobaan yang digunakan yaitu augmented design. Hal ini karena pada percobaan yang digunakan tidak dilakukan pengulangan pada genotipe baru yang diuji, sehingga variasi data antar setiap genotipe pada tiga lingkungan percobaan menjadi lebih besar.

Curah hujan rata-rata selama percobaan di Kabupaten Sumedang, Bandung, dan Karawang berturut-turut adalah $538 \mathrm{~mm}, 198,2 \mathrm{~mm}$, dan 175,32 mm (Tabel 2). Lokasi Kabupaten Karawang dan Bandung merupakan lokasi dengan curah hujan yang lebih kecil dan suhu udara yang

Tabel 4. Hasil analisis varians gabungan pada tujuh varietas cek

\begin{tabular}{lrrrrrr}
\hline Sumber variasi & \multicolumn{1}{c}{ DB } & \multicolumn{1}{c}{ JK } & \multicolumn{1}{c}{ KT } & F-hitung & F-prob. & Persentase (\%) \\
\hline Genotipe (G) & 6 & 97.02 & 16.17 & 3.24 & 0.01 & 10.99 \\
Lingkungan (E) & 2 & 660.72 & 330.36 & 66.26 & 0.00 & 74.84 \\
Interaksi (GxE) & 12 & 125.09 & 10.42 & 2.09 & 0.03 & 14.17 \\
Error & 42 & 209.39 & 4.99 & & & \\
\hline Rata-rata (kg) & 3.54 & & & & & \\
CV $(\%)$ & 45.63 & & & & & \\
\hline
\end{tabular}

Keterangan: $\mathrm{DB}=$ derajat bebas; $\mathrm{JK}=$ jumlah kuadrat; $\mathrm{KT}=$ kuadrat tengah; $\mathrm{CV}=$ koefisien variasi 
lebih tinggi. Oleh karena itu, kebutuhan air pada kedua lokasi tersebut lebih tinggi, sehingga dilakukan penyiraman yang lebih banyak di bandingkan dengan lokasi Kabupaten Sumedang. Menurut Lestari dan Ricky (2015), kebutuhan air pada fase awal dan penanaman sangat penting untuk pertumbuhan tanaman. Opafola et al. (2018) juga menambahkan bahwa suhu yang tinggi, unsur hara yang rendah, dan kekurangan air saat penanaman ubi jalar akan menyebabkan tanaman menjadi stress dan pertumbuhan ubi menjadi tidak maksimal. Berdasarkan hal tersebut, kondisi lingkungan yang cukup basah sangat mendukung pertumbuhan dan pembentukan ubi dalam tanah. Lokasi kabupaten Sumedang memiliki suhu udara pada kisaran 22.50-23.10 ${ }^{\circ} \mathrm{C}$, suhu udara di lokasi kabupaten Bandung berada pada kisaran $24.00-29.00{ }^{\circ} \mathrm{C}$, sedangkan kabupaten Karawang berada pada kisaran 23.00-31.10 ${ }^{\circ} \mathrm{C}$. Suhu optimum untuk pertumbuhan ubi jalar berkisar antara 21.00$27.00{ }^{\circ} \mathrm{C}$ (Opafola et al., 2018). Hasil identifikasi tersebut menunjukkan bahwa kondisi lokasi pengujian kabupaten Sumedang memiliki suhu dan curah hujan yang baik untuk pertumbuhan ubi jalar, sedangkan kabupaten Bandung dan Karawang, kurang mendukung untuk pertumbuhan ubi jalar. Hal ini dikarenakan penanaman pada kedua lokasi tersebut dilakukan pada musim kemarau.

Hasil analisis tanah yang dilakukan di Laboratorium kimia tanah dan nutrisi tanaman, Departemen Ilmu Tanah dan Sumberdaya Lahan, Fakultas Pertanian, Universitas Padjadjaran (Tabel 2). Hasil pengujian menunjukkan bahwa lahan percobaan di Kabupaten Sumedang, Bandung, dan Karawang memiliki kondisi pH, N, P, K, dan C-organik yang menunjang pertumbuhan ubi jalar. Perbedaan kondisi lingkungan percobaan, menyebabkan performa hasil panen dari setiap genotipe ubi jalar menjadi berbeda (Solihin et al., 2018). Hasil uji least significant increase (LSI) yang tersaji pada Tabel 5 menunjukkan perbedaan potensi dari setiap genotipe yang diuji terhadap varietas cek yang digunakan. Genotipe-genotipe pada lokasi kabupaten Sumedang menunjukkan performa hasil yang dominan melebihi varietas cek. Dua puluh genotipe teridentifikasi memiliki potensi hasil yang melebihi seluruh varietas cek, dua genotipe melebihi enam varietas cek, dan lima genotipe tidak melebihi satupun varietas cek. Lokasi kabupaten Bandung menunjukkan performa yang berbeda, dimana tidak ada satupun genotipe baru yang melebihi varietas cek. Lokasi kabupaten Karawang juga menunjukkan performa yang kurang baik, yaitu hanya terdapat satu genotipe yang melebihi satu varietas cek, yaitu genotipe PR79 yang melebihi cek 4. Perbedaan performa hasil setiap genotipe yang diuji pada setiap lokasi pengujian, dikarenakan kondisi lingkungan yang berbeda terutama pada lokasi kabupaten Bandung dan Karawang dengan kondisi yang cukup ektrim, sehingga tanaman yang diuji tercekam oleh kekeringan. Hal ini juga dilaporkan oleh beberapa penelitian sebelumnya yang menyebutkan bahwa cekaman kekeringan sangat mempengaruhi performa hasil tanaman (Lestari and Ricky, 2015; Opafola et al., 2018). Selain itu, latar belakang genetik dan tetua persilangan yang berbeda juga menyebabkan potensi setiap genotipe yang diuji berbeda. Oleh karena itu, penanaman ubi jalar pada musim hujan dan penghujung musim hujan lebih disarankan, agar tanaman ubi jalar mendapatkan asupan air yang cukup selama masa pertumbuhan.

\section{Pengukuran Stabilitas dengan Model Parametrik dan Non- parametrik}

Efek GxE telah banyak dipelajari secara luas oleh para pemulia tanaman dalam menyeleksi genotipe yang stabil dan berdaya hasil tinggi. Berbagai metode telah diusulkan untuk dapat digunakan sebagai indeks seleksi bersama dengan hasil rata-rata peringkat stabilitas genotipe (Farshadfar et al., 2012; Abate et al., 2015; Khalili dan Pour-aboughadareh, 2016; Goksoy et al., 2019; Vaezi et al., 2019). Dalam penelitian ini, digunakan beberapa pengukuran stabilitas parametrik dan non-parametrik, serta model GGE biplot untuk mengidentifikasi genotipe ubi jalar yang stabil dan berdaya hasil tinggi.

Hasil analisis stabilitas parametrik dan non-parametrik ubi jalar disajikan pada Tabel 6, sedangkan peringkat stabilitasnya tersaji pada Tabel 7. Berdasarkan Tabel 6 dan Tabel 7, terlihat bahwa setiap stabilitas memiliki perbedaan dalam mengestimasi genotipe yang stabil. Akan tetapi, terdapat tiga model stabilitas yang memiliki pola sama dalam mengestimasi stabilitas genotipe, yaitu model stabilitas Wricke ekovalens $\left(\mathrm{Wi}^{2}\right)$, varians stabilitas Shukla $\left(\sigma_{\mathrm{i}}^{2}\right)$, dan komponen varians GE Plaisted $\left(\theta_{(\mathrm{i})}\right)$, dengan PR115 dan PR125 sebagai genotipe yang paling stabil. Hal ini menunjukkan bahwa ketiga pengukuran tersebut $\left(\mathrm{Wi}^{2}\right.$, $\left.\sigma_{i}^{2}, \theta_{(i)}\right)$ memiliki kekuatan yang sama dalam mengestimasi stabilitas genotipe, sehingga dapat digunakan salah satu dari ketiga model tersebut untuk menyeleksi genotipe stabil (Vaezi et al., 2017). Berdasarkan nilai rata-rata peringkat, genotipe PR79, C4, PR115, PR125, PR838, PR84, PR20, PR126, PR118, dan PR53 memiliki nilai yang kecil, sehingga dinyatakan paling stabil. Hal serupa juga diungkapkan oleh Vaezi et al. (2019), yang menyebutkan bahwa genotipe yang memiliki nilai rata-rata peringkat paling kecil merupakan genotipe yang memiliki stabilitas hasil paling tinggi pada pengujian multilokasi.

Analisis klaster (dendrogram) digunakan untuk mengelompokkan genotipe-genotipe ubi jalar kedalam kelompok yang jelas. Hasil analisis dendrogram tersaji pada Gambar 1. Dendrogram dari analisis ini memisahkan genotipe ubi jalar menjadi tiga kelompok utama. Kelompok pertama (KI) terdiri dari genotipe PR202, PR191, PR144, PR174, PR136, PR168, PR121, PR235, dan PR196. Kelompok KI memiliki rata-rata hasil panen tinggi dan peringkat rata-rata stabilitas yang tinggi, sehingga mereka merupakan kelompok genotipe tidak stabil dengan hasil panen tinggi. Genotipe-genotipe yang beradaptasi spesifik memiliki keunggulan untuk merespon perubahan lingkungan dibandingkan genotipe yang stabil (Adebola et al., 2013; Laurie et al., 2015; Ngailo et al., 2019). Oleh karena itu, kelompok ini dapat direkomendasikan sebagai varietas unggul spesifik lingkungan.

Kelompok kedua (K2) terdiri dari genotipe C7, C2, C5, $\mathrm{C} 6, \mathrm{C} 3$, dan C1, memiliki hasil panen lebih besar dari rata-rata keseluruhan dan memiliki peringkat rata-rata stabilitas yang 
Tabel 5. Hasil uji least significant increase (LSI) pada setiap lokasi pengujian

\begin{tabular}{|c|c|c|c|c|c|c|c|}
\hline \multirow[b]{2}{*}{ No } & \multirow[b]{2}{*}{ Genotipe } & \multicolumn{2}{|c|}{ Kabupaten Sumedang } & \multicolumn{2}{|c|}{ Kabupaten Bandung } & \multicolumn{2}{|c|}{ Kabupaten Karawang } \\
\hline & & $\begin{array}{c}\text { Nilai } \\
\text { penyesuaian }\end{array}$ & Notasi & $\begin{array}{c}\text { Nilai } \\
\text { penyesuaian }\end{array}$ & Notasi & $\begin{array}{c}\text { Nilai } \\
\text { penyesuaian }\end{array}$ & Notasi \\
\hline 1 & PR17 & 2.16 & - & 0.16 & - & 4.02 & - \\
\hline 2 & PR20 & 4.84 & b-g & 0.17 & - & 2.22 & - \\
\hline 3 & PR39 & 2.41 & - & 0.16 & - & 6.87 & - \\
\hline 4 & PR43 & 2.75 & - & 0.58 & - & 2.17 & - \\
\hline 5 & PR53 & 4.14 & - & 0.17 & - & 2.00 & - \\
\hline 6 & PR54 & 8.29 & $a-g$ & 0.54 & - & 1.60 & - \\
\hline 7 & PR56 & 7.94 & $a-g$ & 0.17 & - & 1.60 & - \\
\hline 8 & PR79 & 9.36 & a-g & 3.31 & - & 9.37 & d \\
\hline 9 & PR84 & 7.24 & $a-g$ & 0.18 & - & 2.27 & - \\
\hline 10 & PR114 & 9.40 & $a-g$ & 0.51 & - & 0.67 & - \\
\hline 11 & PR115 & 6.49 & $a-g$ & 0.51 & - & 0.85 & - \\
\hline 12 & PR118 & 10.89 & $a-g$ & 0.51 & - & 4.23 & - \\
\hline 13 & PR121 & 1.79 & - & 1.56 & - & 5.43 & - \\
\hline 14 & PR125 & 5.64 & $a-g$ & 0.51 & - & 0.10 & - \\
\hline 15 & PR126 & 7.23 & $\mathrm{a}-\mathrm{g}$ & 4.76 & - & 6.62 & - \\
\hline 16 & PR136 & 12.14 & $a-g$ & 0.51 & - & 0.15 & - \\
\hline 17 & PR144 & 10.41 & $\mathrm{a}-\mathrm{g}$ & 0.51 & - & 0.15 & - \\
\hline 18 & PR165 & 5.71 & $a-g$ & 0.51 & - & 0.15 & - \\
\hline 19 & PR168 & 12.07 & $a-g$ & 0.51 & - & 0.15 & - \\
\hline 20 & PR174 & 11.92 & $a-g$ & 0.51 & - & 0.15 & - \\
\hline 21 & PR178 & 4.82 & b-g & 0.51 & - & 0.15 & - \\
\hline 22 & PR179 & 7.57 & $a-g$ & 0.51 & - & 0.15 & - \\
\hline 23 & PR191 & 11.45 & $a-g$ & 0.51 & - & 0.15 & - \\
\hline 24 & PR196 & 14.45 & $a-g$ & 0.56 & - & 0.15 & - \\
\hline 25 & PR202 & 11.17 & $a-g$ & 0.57 & - & 0.15 & - \\
\hline 26 & PR235 & 15.65 & $a-g$ & 0.57 & - & 0.15 & - \\
\hline \multirow[t]{9}{*}{27} & PR838 & 6.20 & $a-g$ & 0.56 & - & 1.02 & - \\
\hline & LSI & 0.68 & & 5.49 & & 3.57 & \\
\hline & Cek 1+LSI & 4.97 & & 6.87 & & 14.94 & \\
\hline & Cek 2+LSI & 4.43 & & 8.07 & & 12.12 & \\
\hline & Cek 3+LSI & 4.56 & & 6.12 & & 12.86 & \\
\hline & Cek 4+LSI & 4.57 & & 6.36 & & 7.03 & \\
\hline & Cek 5+LSI & 4.31 & & 8.92 & & 17.97 & \\
\hline & Cek 6+LSI & 4.78 & & 6.01 & & 13.29 & \\
\hline & Cek 7+LSI & 4.31 & & 6.81 & & 11.64 & \\
\hline
\end{tabular}

Keterangan: $\mathrm{a}=$ melebihi cek 1 (Rancing), $\mathrm{b}=$ melebihi cek 2 (AC-putih), $\mathrm{c}=$ melebihi cek 3 (Keriting maja), d = melebihi cek 4 (Ayamurasaki), e = melebihi cek 5 (Beniazuma), $\mathrm{f}=$ melebihi cek 6 (Kidal), $\mathrm{g}=$ melebihi cek 7 (Beta-2), - = tidak melebihi cek

rendah. Kelompok ini merupakan kelompok ideal, karena memiliki hasil tinggi (di atas rata-rata keseluruhan) serta stabil pada tiga lingkungan pengujian (Vaezi et al., 2019). Akan tetapi, semua genotipe yang berada pada kelompok ini adalah varietas cek, sehingga identifikasi genotipe unggul baru harus dilakukan pada kelompok lainnya.

Kelompok ketiga (K3) terbagi menjadi dua sub kelompok, yaitu sub kelompok genotipe stabil dengan hasil 
Tabel 6. Analisis stabilitas parametrik dan non-parametrik terhadap 34 genotipe ubi jalar

\begin{tabular}{|c|c|c|c|c|c|c|c|c|c|c|c|c|c|c|c|c|c|c|}
\hline Genotipe & asil & (1) & $S^{(2)}$ & $S^{(3)}$ & $S^{(6)}$ & $\mathrm{NP}^{(1)}$ & $\mathrm{NP}^{(2)}$ & $\mathrm{NP}^{(3)}$ & $\mathrm{NP}^{(4)}$ & $K \mathrm{R}$ & $\mathrm{W}_{\mathrm{i}}^{2}$ & $\sigma^{2}{ }_{i}$ & $\mathrm{~s}^{2} \mathrm{~d}_{\mathrm{i}}$ & $b_{i}$ & $\mathrm{CVi}$ & $\theta_{(\mathrm{i})}$ & $\theta_{\mathrm{i}}$ & $\mathrm{V}$ \\
\hline PR17 & 1.58 & .33 & 127.00 & 31.75 & 3.25 & 10.33 & 1.14 & 1.19 & 1.67 & 50 & 0.48 & 0.24 & 0.01 & 0.32 & 86.69 & 0.51 & 0.38 & 0.98 \\
\hline PR20 & 1.87 & .67 & 72.33 & 13.56 & 1.81 & 8.67 & .08 & 0.58 & .00 & 33 & 0.10 & 0.04 & 0.01 & 0.77 & 145.18 & 0.52 & .29 & 0.27 \\
\hline PR39 & 2.61 & 16.00 & 177.33 & 36.69 & 3.17 & 8.33 & 0.69 & 0.82 & 1.66 & 45 & 0.91 & 0.47 & 0.07 & 0.31 & 101.14 & 0.50 & 0.49 & 1.33 \\
\hline PR43 & 1.36 & 15.33 & 132.33 & 16.89 & 1.49 & 12.67 & 0.68 & 0.61 & 0.98 & 49 & 0.40 & 0.20 & 0.00 & 0.36 & 97.44 & 0.51 & 0.36 & 0.71 \\
\hline PR53 & 1.56 & 8.67 & 46.33 & 10.69 & 1.77 & 12.00 & .74 & 1.02 & 1.00 & 39 & 0.15 & 0.07 & 0.01 & 0.66 & 151.52 & 0.52 & 0.30 & 0.38 \\
\hline PR54 & 3.00 & 16.00 & 177.33 & 21.71 & 1.88 & 5.67 & .35 & 0.45 & 0.98 & 36 & 0.43 & 0.21 & 0.05 & 1.24 & 156.9 & 0.51 & 0.37 & 0.47 \\
\hline PR56 & 2.69 & 14.00 & 147.00 & 36.75 & 3.50 & 6.00 & .73 & 0.67 & .75 & 35 & 0.35 & 0.17 & 0.04 & 1.27 & 173.21 & 0.51 & 0.35 & .42 \\
\hline PR79 & 5.95 & 2.00 & 3.00 & 0.25 & 0.15 & 10.67 & .05 & 0.38 & .00 & 16 & 0.40 & 0.20 & 0.05 & 1.27 & 79.57 & 0.51 & 0.36 & .70 \\
\hline PR84 & 2.68 & 12.67 & 109.00 & 16.77 & 1.85 & 3.00 & .40 & 0.27 & .97 & 33 & 0.16 & 0.07 & 0.02 & 1.14 & 151.94 & .52 & 0.30 & .20 \\
\hline PR114 & 3.26 & 15.33 & 134.33 & 20.15 & 1.85 & 8.67 & (1. & 0.50 & .15 & 36 & 0.46 & 0.23 & 0.04 & 1.18 & 159.48 & .51 & 0.38 & 0.57 \\
\hline PR115 & 2.98 & $1+.00$ & 124.33 & 18.20 & 1.85 & 2.05 & (.5 & 0.12 & .02 & 22 & 0.00 & -0.01 & 0.00 & 0.50 & 107.01 & .52 & 0.26 & .27 \\
\hline PR118 & 5.00 & (17.0 & 217.00 & 24.11 & 1.89 & 1.0 & 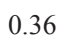 & 0.00 & (6) & 17 & 0.37 & & 0.01 & & 0.01 & .51 & 0.35 & .57 \\
\hline 10121 & 3.27 & 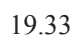 & 254.33 & 26.31 & 1.90 & 10.0J & 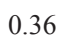 & & . & 41 & 1.85 & (1) & 0.13 & -0.02 & 102.50 & .49 & .14 & 1.80 \\
\hline 1 & 2.70 & 年 & 97.00 & 10.17 & 1.05 & (1.00 & & & 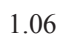 & 29 & 0.03 & & 0.00 & & 114.25 & .52 & 21 & .31 \\
\hline $1 \pi 120$ & 4 & (5) & 146.33 & 19.90 & 1.00 & 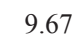 & $0.4 \mathrm{~J}$ & & 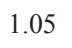 & 16 & 0.12 & 0. & 2 & & 50 & 52 & 5 & .55 \\
\hline $1 \pi 150$ & 4.00 & 0 & 300.00 & 54.55 & 3.64 & (2) & 0.05 & & 1.02 & 37 & 1.34 & 0.69 & 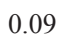 & 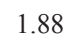 & 21 & 50 & 0.60 & .15 \\
\hline 11014 & 3 & 07 & 208.33 & 47.0 & 3.57 & 1 & 0.00 & 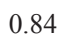 & 1.71 & 30 & 0 & 0.41 & 0.07 & 1 & 21 & 1 & 1 & 83 \\
\hline माराष & 1 & 0 & 75.00 & 25.00 & 3.33 & 9.00 & 1.50 & 1.11 & 1.07 & 3 & 0 & 0.07 & 0.02 & 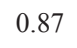 & 1 & 2 & 0 & 15 \\
\hline 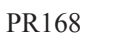 & 4 & 1 & 320.33 & 56.53 & 3.65 & 17.67 & 0.05 & 1.12 & 1.02 & 3 & 1.36 & 0 & y & 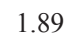 & 11 & 0 & 11 & 17 \\
\hline PR174 & 3.98 & 19.53 & 280.33 & 52.56 & 3.63 & 15.00 & 0.04 & 1. & 1.01 & 37 & 1.31 & 0.00 & 0.09 & 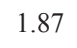 & 21 & .50 & .00 & 1.14 \\
\hline PR178 & 1.61 & 0 & 48.00 & 19.20 & 3.20 & 10.35 & (2) & 1.46 & 1.00 & 39 & 0.16 & 0.07 & 0.02 & ? & 173.21 & .52 & 0.30 & 0.26 \\
\hline PR179 & 2.53 & 15.53 & 133.33 & 34.78 & 3.48 & 5.53 & .00 & 0.62 & 1.14 & 36 & 0.28 & 0.14 & 0.04 & 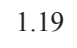 & 21 & .51 & 33 & 0.33 \\
\hline PR191 & 3.82 & 18.67 & 261.33 & 50.58 & 3.61 & 13.33 & 04 & 0.94 & 1. & 37 & 1.15 & 0.60 & 0.08 & 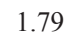 & 173.21 & .50 & 50 & 1.05 \\
\hline PR196 & 4.82 & 2 & 33 & 58 & 3.66 & 20 & . & 1 & 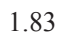 & 50 & 2.37 & 4 & 0.13 & 0 & 21 & 8 & 87 & 1.62 \\
\hline PR202 & 3.73 & 18.00 & 243.00 & 48.60 & 3.60 & 12 & . & 0.88 & ) & 31 & 1.06 & 0.55 & 0.08 & 5 & 21 & 0.50 & 53 & .00 \\
\hline PR235 & 5.22 & 22.00 & 363.00 & 60.50 & 3.67 & 21.33 & 0.05 & 1.26 & 1. & 38 & 2.99 & 1.57 & 0.15 & 2. & 173.21 & 0.47 & 1.03 & 1.85 \\
\hline PR838 & 2.36 & 12.00 & 33 & 15.78 & 1.84 & 0.33 & 2 & 0.33 & 0.97 & 31 & 0.07 & 0.02 & 0.01 & 0.96 & 142.29 & 0.52 & 0.28 & 0.07 \\
\hline C1 & 5.68 & 14.00 & 140.33 & 10.94 & 1.07 & 19.33 & 0.22 & 0.53 & 0.55 & 35 & 2.52 & 1.32 & 0.29 & 0.27 & 90.47 & 0.48 & 0.91 & 1.07 \\
\hline $\mathrm{C} 2$ & 4.96 & 17.33 & 202.33 & 17.34 & 1.40 & 9.00 & 0.28 & 0.46 & 0.74 & 33 & 1.57 & 0.82 & 0.11 & 0.08 & 63.76 & 0.49 & 0.66 & 0.76 \\
\hline $\mathrm{C} 3$ & 4.60 & 15.33 & 156.33 & 14.00 & 1.28 & 15.33 & 0.28 & 0.50 & 0.69 & 37 & 1.80 & 0.94 & 0.20 & 0.35 & 95.09 & 0.49 & 0.72 & 0.67 \\
\hline $\mathrm{C} 4$ & 2.74 & 13.33 & 105.33 & 10.36 & 1.12 & 7.67 & 0.29 & 0.37 & 0.66 & 33 & 0.35 & 0.17 & 0.01 & 0.43 & 59.77 & 0.51 & 0.35 & 0.54 \\
\hline $\mathrm{C} 5$ & 7.15 & 18.67 & 261.33 & 21.19 & 1.51 & 17.67 & 0.28 & 0.55 & 0.76 & 35 & 4.36 & 2.30 & 0.45 & -0.17 & 87.70 & 0.45 & 1.38 & 0.98 \\
\hline C6 & 4.78 & 14.67 & 124.00 & 11.27 & 1.09 & 17.00 & 0.31 & 0.55 & 0.67 & 38 & 1.91 & 1.00 & 0.23 & 0.40 & 97.12 & 0.49 & 0.75 & 0.74 \\
\hline $\mathrm{C} 7$ & 4.34 & 17.33 & 209.33 & 19.32 & 1.54 & 11.67 & .28 & 0.43 & 0.80 & 36 & 1.42 & 0.74 & 0.13 & 0.24 & 79.20 & 0.50 & 0.62 & 0.61 \\
\hline
\end{tabular}

rendah sampai tinggi yang diisi oleh genotipe PR20, PR54, PR56, PR79, PR84, PR114, PR115, PR118, PR125, PR126, PR179, PR838, dan C4. Pada sub kelompok ini genotipe PR79, PR118, dan PR126 merupakan genotipe baru dengan hasil diatas rata-rata keseluruhan dan stabil di tiga lingkungan pengujian. Sub kelompok kedua berisi genotipegenotipe yang memiliki hasil panen rendah serta tidak stabil di semua lingkungan pengujian, mereka adalah PR17, PR39, PR43, PR53, PR165, dan PR178. Beberapa peneliti juga telah berhasil menyeleksi genotipe stabil berdaya hasil tinggi dengan pengukuran stabilitas paramterik dan nonparametrik, diantaranya Khalili dan Pour-aboughadareh (2016) pada tanaman jelai, Goksoy et al. (2019) pada tanaman kedelai, Vaezi et al. (2019) pada tanaman gandum, dan Maulana et al. (2020) pada tanaman ubi jalar. Dengan demikian, genotipe-genotipe pada kelompok ketiga dengan hasil tinggi dan stabil, dapat direkomendasikan sebagai genotipe-genotipe unggul baru yang stabil dan berdaya hasil tinggi.

\section{Korelasi Peringkat Spearman dan Pengelompokan Model Stabilitas pada 34 Genotipe Ubi Jalar}

Berdasarkan koefisien korelasi peringkat Spearman, rata-rata hasil panen (Y) berkorelasi positif dan signifikan dengan $\mathrm{NP}^{(2)}$ dan $\theta_{\mathrm{i}}$ (Tabel 8). Pengukuran stabilitas $\mathrm{NP}^{(2)}$ dan $\theta_{\mathrm{i}}$ termasuk ke dalam model stabilitas statis (Becker dan Leon, 1988). Menurut Vaezi et al. (2019), model stabilitas yang berkorelasi positif dengan hasil panen dapat digunakan untuk merekomendasikan genotipe pada lingkungan yang 
Tabel 7. Peringkat genotipe ubi jalar berdasarkan model stabilitas parametrik dan non-parametrik

\begin{tabular}{|c|c|c|c|c|c|c|c|c|c|c|c|c|c|c|c|c|c|c|c|c|c|c|}
\hline Genotipe & Hasil & $S^{(1)}$ & $S^{(2)}$ & $\mathrm{S}^{(3)}$ & $\begin{array}{l}(6) \\
S^{(6)}\end{array}$ & $\mathrm{NP}^{(1)}$ & $\mathrm{NP}^{(2)}$ & $\mathrm{NP}^{(3)}$ & $\mathrm{NP}^{(4)}$ & $K \mathrm{R}$ & $\mathrm{W}_{\mathrm{i}}{ }^{2}$ & $\sigma^{2}{ }_{i}$ & $\mathrm{~s}^{2} \mathrm{~d}_{\mathrm{i}}$ & bi & $\mathrm{CVi}$ & $\theta_{(i)}$ & $\theta_{\mathrm{i}}$ & ASV & SR & AR & $\mathrm{SD}$ & RAR \\
\hline PR17 & 32 & 9 & 12 & 23 & 23 & 16 & 31 & 31 & 23 & 34 & 18 & 18 & 7 & 21 & 5 & 18 & 17 & 24 & 362 & 20.11 & 8.31 & 24 \\
\hline PR20 & 29 & 5 & 4 & 6 & 11 & 11 & 30 & 17 & 14 & 7 & 4 & 4 & 6 & 8 & 18 & 4 & 31 & 5 & 214 & 11.89 & 9.15 & 7 \\
\hline PR39 & 25 & 20 & 20 & 25 & 21 & 10 & 27 & 22 & 22 & 31 & 20 & 20 & 20 & 22 & 13 & 20 & 15 & 31 & 384 & 21.33 & 5.25 & 26 \\
\hline PR43 & 34 & 16 & 13 & 11 & 7 & 24 & 24 & 18 & 12 & 33 & 15 & 15 & 3 & 19 & 12 & 15 & 20 & 19 & 310 & 17.22 & 7.71 & 21 \\
\hline PR53 & 33 & 3 & 2 & 3 & 10 & 22 & 33 & 27 & 14 & 29 & 6 & 6 & 4 & 13 & 19 & 6 & 29 & 9 & 268 & 14.89 & 10.89 & 10 \\
\hline PR54 & 20 & 20 & 20 & 19 & 18 & 6 & 9 & 8 & 13 & 14 & 16 & 16 & 18 & 9 & 21 & 16 & 19 & 11 & 273 & 15.17 & 4.63 & 11 \\
\hline PR56 & 23 & 12 & 18 & 26 & 26 & 7 & 29 & 21 & 26 & 11 & 12 & 12 & 16 & 11 & 28 & 12 & 23 & 10 & 323 & 17.94 & 7.08 & 22 \\
\hline PR79 & 2 & 1 & 1 & 1 & 1 & 20 & 1 & 6 & 1 & 1 & 14 & 14 & 17 & 12 & 4 & 14 & 21 & 18 & 149 & 8.28 & 7.51 & 1 \\
\hline PR84 & 24 & 7 & 9 & 10 & 14 & 2 & 13 & 2 & 11 & 7 & 9 & 9 & 13 & 5 & 20 & 9 & 26 & 3 & 193 & 10.72 & 6.67 & 6 \\
\hline PR114 & 19 & 16 & 15 & 17 & 15 & 11 & 15 & 10 & 20 & 14 & 17 & 17 & 15 & 14 & 22 & 17 & 18 & 15 & 287 & 15.94 & 2.82 & 13 \\
\hline PR115 & 21 & 12 & 11 & 13 & 16 & 1 & 12 & 1 & 17 & 4 & 1 & 1 & 1 & 3 & 15 & 1 & 34 & 6 & 170 & 9.44 & 8.84 & 3 \\
\hline PR118 & 4 & 23 & 25 & 20 & 19 & 8 & 11 & 16 & 9 & 3 & 13 & 13 & 8 & 16 & 10 & 13 & 22 & 14 & 247 & 13.72 & 6.15 & 9 \\
\hline PR121 & 18 & 29 & 27 & 22 & 20 & 16 & 10 & 20 & 14 & 32 & 29 & 29 & 28 & 32 & 14 & 29 & 6 & 33 & 408 & 22.67 & 8.02 & 28 \\
\hline PR125 & 27 & 7 & 6 & 9 & 12 & 4 & 16 & 4 & 19 & 5 & 2 & 2 & 2 & 6 & 16 & 2 & 33 & 7 & 179 & 9.94 & 8.75 & 4 \\
\hline PR126 & 11 & 16 & 17 & 16 & 17 & 15 & 14 & 12 & 18 & 1 & 5 & 5 & 11 & 1 & 7 & 5 & 30 & 13 & 214 & 11.89 & 6.96 & 8 \\
\hline PR136 & 13 & 31 & 31 & 31 & 31 & 28 & 20 & 28 & 31 & 19 & 24 & 24 & 24 & 29 & 28 & 24 & 11 & 29 & 456 & 25.33 & 5.97 & 31 \\
\hline PR144 & 17 & 22 & 23 & 27 & 27 & 16 & 25 & 23 & 27 & 14 & 19 & 19 & 19 & 18 & 28 & 19 & 16 & 22 & 381 & 21.17 & 4.23 & 25 \\
\hline PR165 & 30 & 4 & 5 & 21 & 24 & 13 & 32 & 29 & 23 & 19 & 7 & 7 & 12 & 4 & 28 & 7 & 28 & 2 & 295 & 16.39 & 10.35 & 18 \\
\hline PR168 & 12 & 32 & 32 & 32 & 32 & 30 & 21 & 30 & 32 & 19 & 25 & 25 & 25 & 30 & 23 & 25 & 10 & 30 & 465 & 25.83 & 6.59 & 32 \\
\hline PR174 & 14 & 29 & 30 & 30 & 30 & 26 & 19 & 26 & 30 & 19 & 23 & 23 & 23 & 28 & 25 & 23 & 12 & 28 & 438 & 24.33 & 5.3 & 30 \\
\hline PR178 & 31 & 2 & 3 & 14 & 22 & 16 & 34 & 34 & 21 & 29 & 8 & 8 & 10 & 10 & 25 & 8 & 27 & 4 & 306 & 17 & 10.71 & 20 \\
\hline PR179 & 26 & 9 & 14 & 24 & 25 & 3 & 26 & 19 & 25 & 14 & 10 & 10 & 14 & 7 & 23 & 10 & 25 & 8 & 292 & 16.22 & 7.63 & 16 \\
\hline PR191 & 15 & 27 & 28 & 29 & 29 & 25 & 18 & 25 & 29 & 19 & 22 & 22 & 22 & 26 & 28 & 22 & 13 & 26 & 425 & 23.61 & 4.73 & 29 \\
\hline PR196 & 7 & 33 & 33 & 33 & 33 & 33 & 22 & 32 & 33 & 26 & 31 & 31 & 29 & 33 & 28 & 31 & 4 & 32 & 504 & 28 & 8.47 & 33 \\
\hline PR202 & 16 & 26 & 26 & 28 & 28 & 22 & 17 & 24 & 28 & 19 & 21 & 21 & 21 & 24 & 25 & 21 & 14 & 25 & 406 & 22.56 & 4.07 & 27 \\
\hline PR235 & 5 & 34 & 34 & 34 & 34 & 34 & 23 & 33 & 34 & 26 & 33 & 33 & 30 & 34 & 28 & 33 & 2 & 34 & 518 & 28.78 & 9.47 & 34 \\
\hline PR838 & 28 & 6 & 7 & 8 & 13 & 5 & 28 & 3 & 10 & 6 & 3 & 3 & 9 & 2 & 17 & 3 & 32 & 1 & 184 & 10.22 & 9.43 & 5 \\
\hline $\mathrm{C} 1$ & 3 & 12 & 16 & 4 & 2 & 32 & 2 & 13 & 2 & 11 & 32 & 32 & 33 & 23 & 8 & 32 & 3 & 27 & 287 & 15.94 & 12.17 & 14 \\
\hline $\mathrm{C} 2$ & 6 & 23 & 22 & 12 & 6 & 13 & 6 & 9 & 6 & 7 & 27 & 27 & 26 & 31 & 2 & 27 & 8 & 21 & 279 & 15.5 & 9.45 & 12 \\
\hline $\mathrm{C} 3$ & 9 & 16 & 19 & 7 & 5 & 27 & 5 & 11 & 5 & 19 & 28 & 28 & 31 & 20 & 9 & 28 & 7 & 17 & 291 & 16.17 & 9.01 & 15 \\
\hline $\mathrm{C} 4$ & 22 & 9 & 8 & 2 & 4 & 8 & 7 & 5 & 3 & 7 & 11 & 11 & 5 & 15 & 1 & 11 & 24 & 12 & 165 & 9.17 & 6.09 & 2 \\
\hline C5 & 1 & 27 & 29 & 18 & 8 & 30 & 3 & 15 & 7 & 11 & 34 & 34 & 34 & 27 & 6 & 34 & 1 & 23 & 342 & 19 & 12.21 & 23 \\
\hline C6 & 8 & 15 & 10 & 5 & 3 & 29 & 8 & 14 & 4 & 26 & 30 & 30 & 32 & 17 & 11 & 30 & 5 & 20 & 297 & 16.5 & 10.21 & 19 \\
\hline C7 & 10 & 23 & 24 & 15 & 9 & 21 & 4 & 7 & 8 & 14 & 26 & 26 & 27 & 25 & 3 & 26 & 9 & 16 & 293 & 16.28 & 8.29 & 17 \\
\hline
\end{tabular}

Keterangan : $\mathrm{SR}=$ jumlah peringkat stabilitas; $\mathrm{AR}=$ rata-rata peringkat stabilitas; $\mathrm{SD}=$ standar deviasi; $\mathrm{RAR}=$ peringkat dari $\mathrm{AR}$

kurang menguntungkan (unfavorable). Oleh karena itu, pengukuran stabilitas $\mathrm{NP}^{(2)}$ dan $\theta_{\mathrm{i}}$ termasuk dalam kelompok ini.

Korelasi positif dan signifikan lainnya yaitu $\mathrm{S}^{(1)}$ terhadap $\mathrm{S}^{(2)}, \mathrm{S}^{(3)}, \mathrm{S}^{(6)}, \mathrm{NP}^{(1)}, \mathrm{Wi}^{2}, \sigma^{2}$, $\mathrm{S}_{\text {din }}$, bi, $\theta_{(\mathrm{i})}$, dan ASV, serta berkorelasi negatif dan signifikan terhadap $\theta_{\mathrm{i}} . \mathrm{S}^{(2)}$ berkorelasi positif dan signifikan terhadap $\mathrm{S}^{(3)}, \mathrm{S}^{(6)}, \mathrm{NP}^{(1)}$, $\mathrm{Wi}^{2}, \sigma^{2}{ }_{i}, \mathrm{~S}_{\text {di }}^{2}$, bi, $\theta_{(\mathrm{i})}$, dan ASV, serta berkorelasi negatif dan signifikan terhadap $\theta_{i}$. $S^{(3)}$ berkorelasi positif dan signifikan terhadap $\mathrm{S}^{(6)}, \mathrm{NP}^{(3)}$, $\mathrm{NP}^{(4)}$, bi, CVi, dan ASV. Model stabilitas $\mathrm{S}^{(6)}$ berkorelasi positif dan signifikan terhadap $\mathrm{NP}^{(2)}, \mathrm{NP}^{(3)}$, $\mathrm{NP}^{(4)}$, dan $\mathrm{CVi}$. $\mathrm{NP}^{(1)}$ berkorelasi positif terhadap $\mathrm{NP}^{(3)}, \mathrm{KR}$, $\mathrm{Wi}^{2}, \sigma^{2}, \mathrm{~S}^{2} \mathrm{~d}_{\mathrm{i}}, \mathrm{bi}, \theta_{(\mathrm{i})}$, dan ASV serta berkorelasi negatif dengan $\theta_{\mathrm{i}}$. $\mathrm{NP}^{(2)}$ berkorelasi positif dan signifikan terhadap $\mathrm{NP}^{(3)}$, $\mathrm{NP}^{(4)}$, dan KR. NP(3) berkorelasi positif dan signifikan dengan $\mathrm{NP}^{(4)}$, $\mathrm{KR}$, dan $\mathrm{CVi}$. $\mathrm{NP}^{(4)}$ berkorelasi positif dan signifikan dengan CVi. Model stabilitas KR berkorelasi positif dan signifikan dengan bi.

Model stabilitias $\mathrm{Wi}^{2}$ berkorelasi positif dan nyata terhadap $\sigma^{2}{ }_{i}, S^{2}$ di, bi, $\theta_{(i)}$, dan ASV, serta berkorelasi negatif dan nyata dengan $\theta_{\mathrm{i}}$. Model stabilitas $\sigma^{2}{ }_{\mathrm{i}}$ berkorelasi positif dengan $\mathrm{S}^{2}$ di, bi, $\theta_{(\mathrm{i})}$, dan $\mathrm{ASV}$, serta berkorelasi negatif dengan $\theta_{i}$. Model stabilitas $\mathrm{S}^{2} \mathrm{~d}_{\mathrm{i}}$ berkorelasi positif dan signifikan terhadap bi, $\theta_{(\mathrm{i})}$, dan ASV serta berkorelasi negatif dan signifikan dengan $\theta_{\mathrm{i}}$. Model stabilitas bi berkorelasi positif dan signifikan terhadap $\theta_{(\mathrm{i})}$ dan ASV, serta berkorelasi negatif dengan $\theta_{\mathrm{i}}$. Model stabilitas $\theta_{\text {(i) }}$ berkorelasi positif signifikan dengan ASV dan berkorelasi negatif signifikan dengan $\theta_{\mathrm{i}}$. Model stabilitas $\theta_{\mathrm{i}}$ berkorelasi negatif dan signifikasn terhadap ASV. 


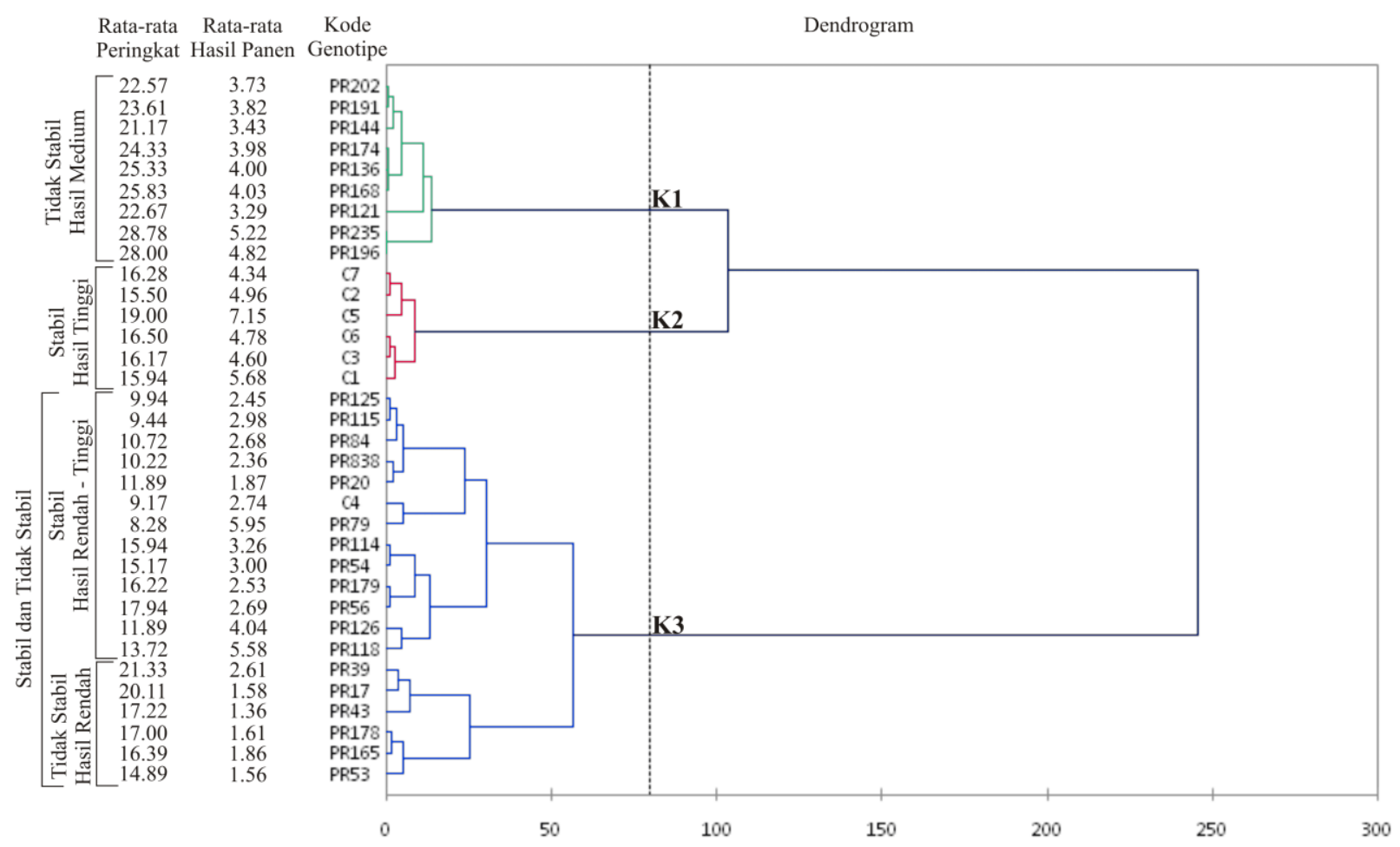

Gambar 1. Pengelompokkan genotipe ubi jalar berdasarkan hasil panen dan peringkat stabilitas

Principal component analysis (PCA) digunakan untuk mengelompokkan model stabilitas. Lima PC pertama dengan eigenvalue $>1$ bernilai $90.08 \%$ dari total variasi (Tabel 9). Karena dua komponen pertama memiliki nilai variabilitas tertinggi (masing-masing 39.67\% dan 27.37\%) dan eigenvalue (masing-masing 13.49 dan 9.31), maka PCA di ektsrak dari kedua komponen tersebut (PC1 dan PC2) (Khalili and Pour-aboughadareh, 2016; Vaezi et al., 2017). Hasil analisis PCA tersaji pada Gambar 2.

Gambar 2 menunjukkan pengelompokkan model stabilitas parametrik dan non-parametrik. Model-model yang digunakan diklasifikasikan menjadi empat kelompok utama, yaitu kelompok pertama (K1) berisi model stabilitas $\mathrm{CVi}, \mathrm{S}^{(3)}, \mathrm{S}^{(6)}$, dan $\mathrm{NP}^{(4)}$. Kelompok kedua (K2) berisi model stabilitas $\mathrm{S}^{(1)}, \mathrm{S}^{(2)}, \mathrm{ASV}$, bi, $\mathrm{NP}^{(1)}, \mathrm{S}^{2} \mathrm{di}, \mathrm{Wi}^{2}$, dan $\sigma^{2}{ }_{\mathrm{i}}$. Kelompok ketiga (K3) berisi model stabilitas $\mathrm{NP}^{(3)}$ dan KR. Ketiga kelompok ini merepresentasikan model stabilitas dinamis, karena berada pada kelompok berbeda dengan hasil (Mohammadi dan Amri, 2008). Menurut beberapa penelitian, kelompok ini dapat merekomendasikan genotipe pada lingkungan yang menguntungkan (favorable) (Farshadfar et al., 2012; Khalili dan Pour-aboughadareh, 2016; Vaezi et al., 2019). Kelompok keempat (K4) berisi hasil (Y) dan model stabilitas $\mathrm{NP}^{(2)}$ dan $\theta_{\mathrm{i}}$, kedua model ini merupakan model stabilitas statis, yang dapat merekomendasikan genotipe pada lingkungan yang kurang menguntungkan.

\section{Stabilitas Hasil Berdasarkan GGE Biplot}

Visualisasi stabilitas hasil genotipe-genotipe ubi jalar, menggunakan analisis GGE biplot. Hasil analisis GGE biplot pada 34 genotipe ubi jalar, menunjukkan bahwa PC1 dan PC2 masing-masing menyumbang 72.5 dan $26.2 \%$ dari total variasi hasil panen ubi jalar (Gambar 3). Pola 'which won where' menunjukkan bahwa tiga lokasi memiliki tujuh sektor dengan genotipe puncak yang berbeda. Terdapat dua lingkungan yang berada pada sektor yang sama (Sektor 1) yaitu Bandung dan Karawang dengan genotipe puncak C1. Genotipe puncak pada lokasi Sumedang yaitu genotipe PR235. Genotipe-genotipe yang berada pada puncak setiap sektor menunjukkan bahwa genotipe-genotipe tersebut memiliki hasil tinggi pada lingkungan yang berada di sektor tersebut ( $\operatorname{Rad}$ et al., 2013; Zhang et al., 2016; Mustamu et al., 2018). Genotipe-genotipe yang berada pada sektor yang berisi lebih dari satu lingkungan atau lingkungan mega, menunjukkan genotipe yang ideal (Xu et al., 2014; Gurmu, 2017; Erdemci, 2018). Oleh karena itu, pada pengujian ini genotipe-genotipe yang termasuk ideal adalah PR79, PR121, PR126, C1, C2, C3, C5, dan C6. Hasil pengujian juga menunjukkan bahwa genotipe puncak yang terletak pada sektor yang tidak berisi lingkungan, memiliki hasil panen yang rendah di semua lokasi pengujian, sehingga genotipegenotipe pada sektor ini kurang direkomendasikan.

Hasil analisis GGE biplot menunjukkan bahwa beberapa genotipe teridentifikasi mendekati titik pusat sumbu. Genotipe-genotipe tersebut adalah PR54, PR56, PR79, PR84, PR114, PR115, PR125, PR126, PR144, PR168, PR174, PR 179, PR191, dan PR202. Beberapa peneliti mengungkapkan bahwa genotipe yang berada dekat dengan sumbu pusat (0.00), merupakan genotipe yang stabil (Zhang et al., 2016; Mustamu et al., 2018). Hasil pengukuran GGE biplot, parametrik dan non-parametrik, menunjukkan pola 
Tabel 8. Korelasi peringkat Spearman hasil panen terhadap model stabilitas parametrik dan non-parametrik pada 34 genotipe ubi jalar

\begin{tabular}{|c|c|c|c|c|c|c|c|c|c|c|c|c|c|c|c|c|c|}
\hline Model & Hasil & $\mathrm{S}^{(1)}$ & $\mathrm{S}^{(2)}$ & $S^{(3)}$ & $S^{(6)}$ & $\mathrm{NP}^{(1)}$ & $\mathrm{NP}^{(2)}$ & $\mathrm{NP}^{(3)}$ & $\mathrm{NP}^{(4)}$ & $K \mathrm{R}$ & $\mathrm{W}_{\mathrm{i}}^{2}$ & $\sigma_{i}^{2}$ & $\mathrm{~s}^{2} \mathrm{~d}_{\mathrm{i}}$ & bi & $\mathrm{CVi}$ & $\theta_{(\mathrm{i})}$ & $\theta_{\mathrm{i}}$ \\
\hline \multicolumn{18}{|l|}{ Hasil } \\
\hline$S^{(1)}$ & $-0.57^{*}$ & & & & & & & & & & & & & & & & \\
\hline$S^{(2)}$ & $-0.58^{*}$ & $0.98^{* *}$ & & & & & & & & & & & & & & & \\
\hline $\mathrm{S}^{(3)}$ & -0.13 & $0.72 * *$ & $0.78^{* *}$ & & & & & & & & & & & & & & \\
\hline$S^{(6)}$ & 0.08 & $0.51^{*}$ & $0.57^{*}$ & $0.93^{* *}$ & & & & & & & & & & & & & \\
\hline $\mathrm{NP}^{(1)}$ & $-0.52^{*}$ & $0.53^{*}$ & $0.51^{*}$ & 0.26 & 0.14 & & & & & & & & & & & & \\
\hline $\mathrm{NP}^{(2)}$ & $0.73^{* *}$ & -0.24 & -0.20 & 0.34 & $0.55^{*}$ & -0.14 & & & & & & & & & & & \\
\hline $\mathrm{NP}^{(3)}$ & 0.10 & 0.33 & 0.38 & $0.67^{*}$ & $0.71^{* *}$ & $0.54 *$ & $0.63^{*}$ & & & & & & & & & & \\
\hline $\mathrm{NP}^{(4)}$ & 0.19 & 0.43 & 0.47 & $0.87^{* *}$ & $0.95^{* *}$ & 0.17 & $0.64^{*}$ & $0.73^{* *}$ & & & & & & & & & \\
\hline$K \mathrm{R}$ & 0.27 & 0.28 & 0.25 & 0.39 & 0.36 & $0.50^{*}$ & 0.43 & $0.73^{* *}$ & 0.41 & & & & & & & & \\
\hline $\mathrm{W}_{\mathrm{i}}^{2}$ & $-0.69^{*}$ & $0.73 * *$ & $0.73^{* *}$ & 0.36 & 0.10 & $0.77^{* *}$ & -0.42 & 0.30 & 0.05 & 0.42 & & & & & & & \\
\hline$\sigma_{i}^{2}$ & $-0.69^{*}$ & $0.73 * *$ & $0.73 * *$ & 0.36 & 0.10 & $0.77 * *$ & -0.42 & 0.30 & 0.05 & 0.42 & $1.00^{* *}$ & & & & & & \\
\hline $\mathrm{s}^{2} \mathrm{~d}_{\mathrm{i}}$ & $-0.74 * *$ & $0.64 *$ & $0.67 *$ & 0.33 & 0.10 & $0.69^{*}$ & -0.44 & 0.21 & 0.03 & 0.26 & $0.92^{* *}$ & $0.92 * *$ & & & & & \\
\hline $\mathrm{Bi}$ & $-0.52^{*}$ & $0.81^{* *}$ & $0.79^{* *}$ & $0.50^{*}$ & 0.29 & $0.74^{* *}$ & -0.21 & 0.48 & 0.26 & $0.51^{*}$ & $0.89^{* *}$ & $0.89^{* *}$ & $0.72^{* *}$ & & & & \\
\hline Cvi & 0.22 & 0.22 & 0.28 & $0.66^{*}$ & $0.80^{* *}$ & 0.10 & $0.60^{*}$ & $0.59^{*}$ & $0.82^{* * *}$ & 0.31 & -0.04 & -0.04 & 0.05 & 0.06 & & & \\
\hline$\theta_{(\mathrm{i})}$ & $-0.69 *$ & $0.73^{* *}$ & $0.73 * *$ & 0.36 & 0.10 & $0.77^{* *}$ & -0.42 & 0.30 & 0.05 & 0.42 & $1.00^{* * *}$ & $1.00^{* *}$ & $0.92 * *$ & $0.89^{* *}$ & -0.04 & & \\
\hline$\theta_{\mathrm{i}}$ & $0.69^{*}$ & $-0.73^{* *}$ & $-0.73 * *$ & -0.36 & -0.10 & $-0.77^{* *}$ & 0.42 & -0.30 & -0.05 & -0.42 & $-1.00^{* *}$ & $-1.00^{* *}$ & $-0.92 * *$ & $-0.89^{* *}$ & 0.04 & $-1.00^{* *}$ & \\
\hline ASV & $-0.54 *$ & $0.80^{* *}$ & $0.78^{* *}$ & $0.56^{*}$ & 0.35 & $0.72 * *$ & -0.20 & 0.47 & 0.33 & 0.49 & $0.84 * *$ & $0.84 * *$ & $0.69^{*}$ & $0.91 * *$ & 0.07 & $0.84 * *$ & $-0.84 * *$ \\
\hline
\end{tabular}

Keterangan: *menunjukkan korelasi yang signifikan pada taraf $5 \%(\mathrm{p}<0.05) ; * *$ menunjukkan korelasi yang signifikan pada taraf 1 $(p<0.01)$

Tabel 9. Eigenvalue, variability, dan cumulative model stabilitas parametrik dan non-parametrik pada 34 genotipe ubi jalar

\begin{tabular}{lcrrrr}
\hline PC & 1 & 2 & 3 & \multicolumn{1}{c}{4} & \multicolumn{1}{c}{5} \\
\hline Eigenvalue & 13.49 & 9.31 & 3.84 & 2.16 & 1.83 \\
Variability (\%) & 39.67 & 27.37 & 11.30 & 6.34 & 5.39 \\
Cumulative (\%) & 39.67 & 67.05 & 78.35 & 84.69 & 90.08 \\
\hline
\end{tabular}

Keterangan: $\mathrm{PC}=$ Principal component

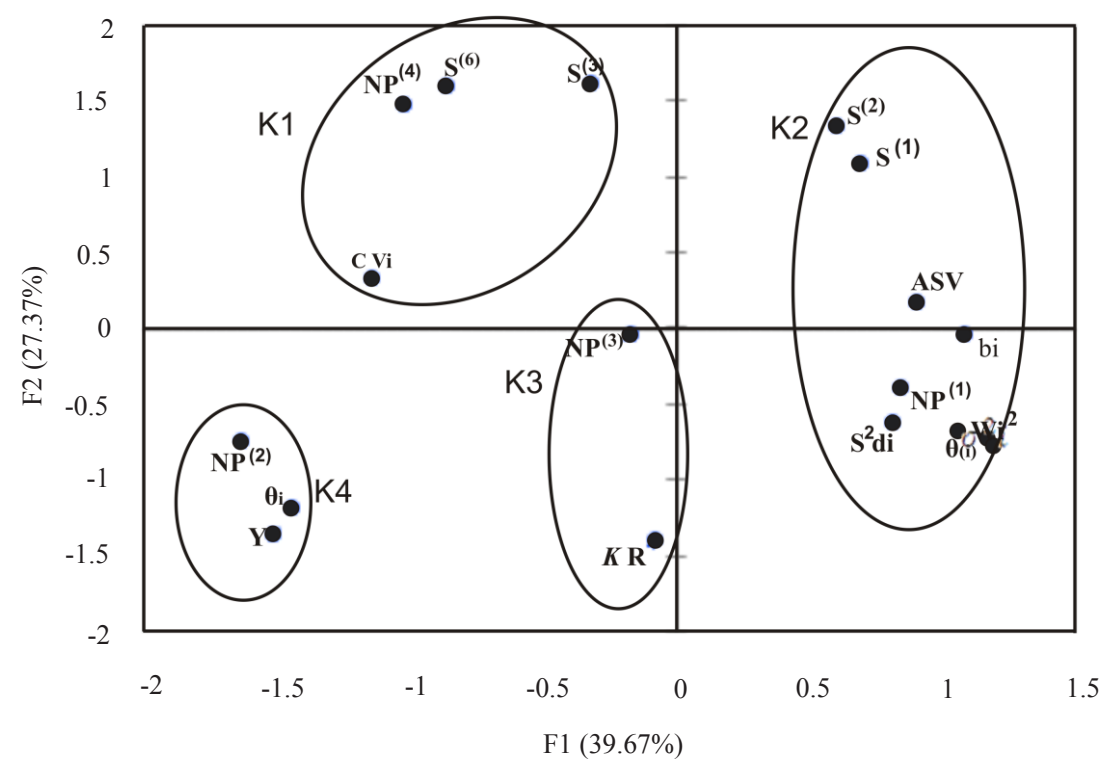

Gambar 2. Pengelompokkan model stabilitas pada 34 genotipe ubi jalar berdasarkan PCA 


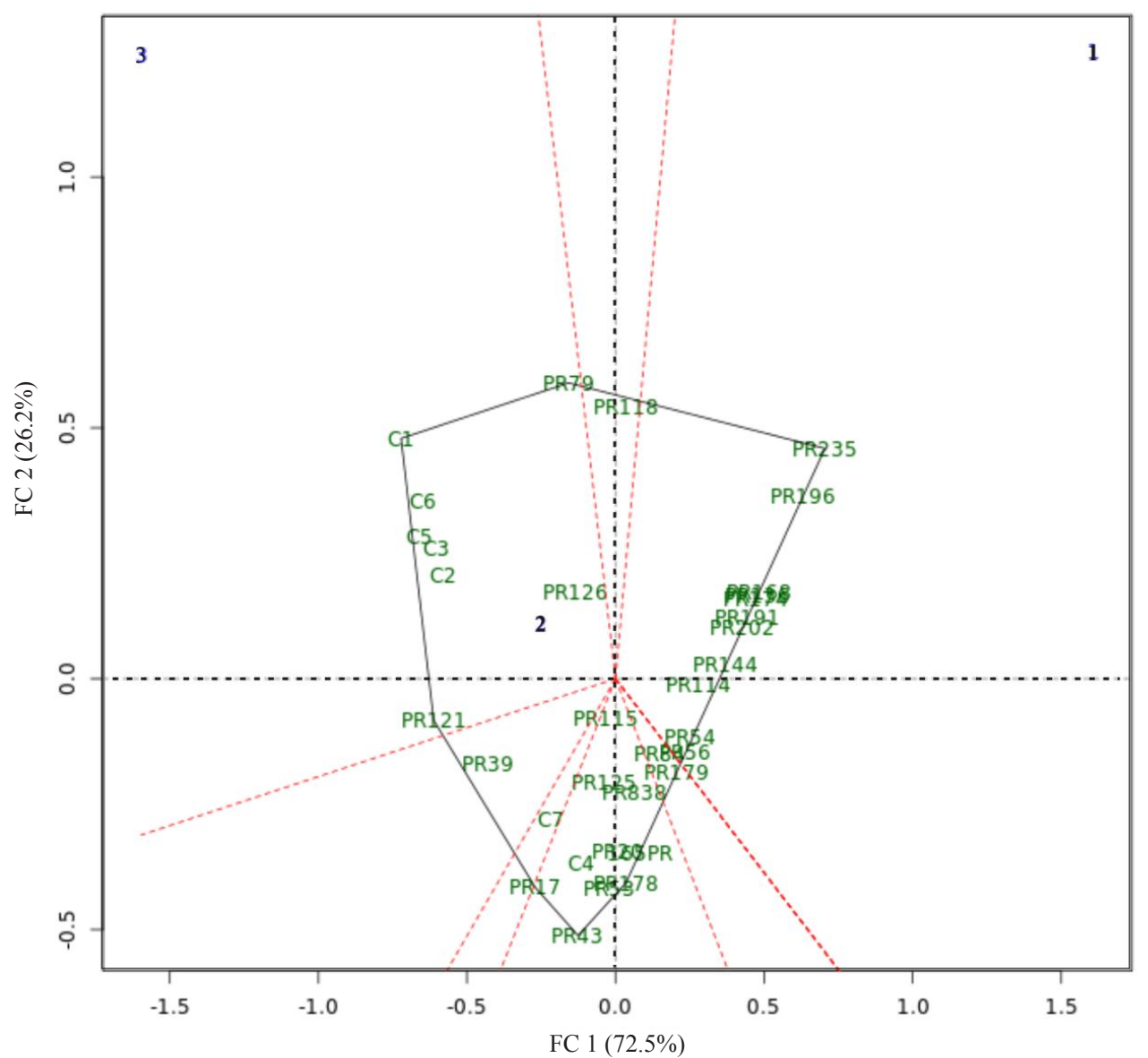

Gambar 3. Grafik GGE biplot "which won where” pada 34 genotipe ubi jalar $(1$ = Kabupaten Sumedang, 2 = Kabupaten Bandung, $3=$ Kabupaten Karawang)

yang mirip dalam menyeleksi genotipe ideal (stabil dan berdaya hasil tinggi). Berdasarkan gabungan pendekatan model stabilitas, terseleksi dua genotipe baru yang ideal pada tiga lingkungan pengujian, yaitu genotipe PR79 dan PR126. Kedua genotipe tersebut dapat direkomendasikan sebagai genotipe unggul baru yang stabil dan berdaya hasil tinggi pada tiga lingkungan pengujian dan sebagai bahan untuk program pemuliaan tanaman ubi jalar selanjutnya.

\section{KESIMPULAN}

Efek interaksi genotipe dengan lingkungan (GxE) berpengaruh secara signifikan terhadap hasil panen ubi jalar dengan kontribusi sebesar 14.17\%. Dua genotipe terseleksi memilik hasil yang tinggi dan stabil pada tiga lokasi pengujian berdasarkan pengukuran stabilitas parametrik, non-parametrik, dan GGE biplot, yaitu PR79 dan PR126. Pengukuran $\mathrm{NP}^{(2)}$ dan $\theta_{\mathrm{i}}$ termasuk model pengukuran stabilitas statis yang dapat merekomendasikan genotipe stabil pada lingkungan yang kurang menguntungkan (unfavorable), sedangkan pengukuran $\mathrm{S}^{(1)}, \mathrm{S}^{(2)}, \mathrm{S}^{(3)}, \mathrm{S}^{(6)}, \mathrm{NP}^{(1)}$, $\mathrm{NP}^{(3)}, \mathrm{NP}^{(4)}, \mathrm{KR}, \mathrm{CVi}, \mathrm{bi}, \mathrm{S}^{2} \mathrm{di}, \mathrm{Wi}^{2}, \mathrm{ASV}$, dan $\sigma^{2}{ }_{\mathrm{i}}$ merupakan model stabilitas dinamis yang dapat merekomendasikan genotipe stabil pada lingkungan yang menguntungkan (favorable).

\section{UCAPAN TERIMA KASIH}

Penelitian ini didanai oleh RISPRO-LPDP, Kementerian Keuangan Republik Indonesia (No. Kontrak: 41/LPDP/2018). Terima kasih kepada Koko Tjintokohadi (CIP-ESEAP) dan Wolfgang Gruneberg (CIP-Peru) yang telah memberikan materi genetik ubi jalar.

\section{DAFTAR PUSTAKA}

Abate, F., F. Mekbib, Y. Dessalegn. 2015. Association of different parametric and non parametric stability models in durum wheat (Triticum turgidum Desf .) genotypes. Int. J. Plant Soil Sci. 7:192-201.

Adebola, P.O., A. Shegro, S.M. Laurie, L.N. Zulu, M. Pillay. 2013. Genotype x environment interaction and yield stability estimate of some sweet potato [Ipomoea batatas (L.) Lam] breeding lines in South Africa. J. Plant Breed. Crop Sci. 5:182-186.

Ahmadi, J., B. Vaezi, A. Shaabani, K. Khademi, S.F. Ourang. 2015. Non-parametric measures for yield stability in grass pea (Lathyrus sativus L.) advanced lines in semi warm regions. J. Agric. Sci. Technol. 17:1825-1838. 
Ajay, B.C., S.K. Bera, A.L. Singh, N. Kumar, K. Gangadhar, P. Kona. 2020. Evaluation of genotype x environment interaction and yield stability analysis in peanut under phosphorus stress condition using stability parameters of AMMI model. Agric. Res. 9:1-10.

Andrade, M.I., A. Naico, J. Ricardo, R. Eyzaguirre, G.S. Makunde, R. Ortiz, W.J. Gruneberg. 2016a. Genotype $\mathrm{x}$ environment interaction and selection for drought adaptation in sweetpotato (Ipomoea batatas [L.] Lam.) in Mozambique. Euphytica 209:261-280.

Andrade, M.I., J. Ricardo, A. Naico, A. Alvaro, G.S. Makunde, J. Low, R. Ortiz, W.J. Gruneberg. 2016 b. Release of orange-fleshed sweetpotato (Ipomoea batatas [L.] Lam.) cultivars in Mozambique through an accelerated breeding scheme. J. Agric. Sci. 2016: $1-11$.

Becker, H.C., J. Leon. 1988. Stability analysis in plant breeding. Plant Breed. 101:1-23.

Dia, M., T.C. Wehner, C. Arellano. 2016. Analysis of genotype $\times$ environment interaction $(\mathrm{G} \times \mathrm{E})$ using SAS programming. Agron. J. 108:1838-1852.

Eberhart, S.A., W.A. Russell. 1966. Stability parameters for comparing varieties. Crop Sci. 6:36-40.

Erdemci, I. 2018. Investigation of genotype $\times$ environment interaction in chickpea genotypes using AMMI and GGE biplot analysis. Turkish J. F. Crop. 23:20-26. doi: $10.17557 /$ tjfc.414846.

Farshadfar, E., S.H. Sabaghpour, H. Zali. 2012. Comparison of parametric and non-parametric stability statistics for selecting stable chickpea (Cicer arietinum L.) genotypes under diverse environments. Aust. J. Crop Sci. 6:514-524.

Francis, T.R., L.W. Kannenberg. 1978. Yield stability studies in short-season maize: I. A descriptive method for grouping genotypes. Can. J. Plant Sci. 5:1029-1034.

Goksoy, A.T., M. Sincik, M. Erdogmus, M. Ergin, S. Aytac. G. Gumuscu, O. Gunduz, R. Keles, G. Bayram, E. Seyigit. 2019. The parametric and non-parametric stability analyses for interpreting genotype by environment interaction of some soybean genotypes. Turkish J. Fiel Crops 24:28-38.

Gurmu, F. 2017. Stability analysis of fresh root yield of sweetpotato in Southern Ethiopia using GGE biplot. Int. J. Pure Agric. Adv. 1:1-9.

Haldavanekar, P.C., S.G. Bhave, R.G. Kahandekar, S.G. Kadam, S.S. Sawant. 2011. Stability analysis in sweet potato (Ipomea batatas L.). Karnatakan J. Agric. Sci. 24:358-361.
Hariadi, H., M. Sunyoto, B. Nurhadi, A. Karuniawan. 2018. Comparison of phytochemical characteristics pigmen extract (Antosianin) sweet purple potatoes powder (Ipomoea batatas L) and clitoria flower (Clitoria ternatea) as natural dye powder. J. Pharmacogn. Phytochem. 7:3420-3429.

Hastini, T., W.B. Suwarno, M. Ghulamahdi, H. Aswidinnoor. 2020. Interaksi genotipe $\times$ musim karakter percabangan malai tiga genotipe padi sawah. J. Agron. Indonesia 48:1-7.

Huehn, M. 1990. Nonparametric measures of phenotypic stability . Part 1 : Theory. Euphytica 47:189-194.

Kang, M.S. 1988. A rank-sum method for selecting highyielding, stable corn genotypes. Cereal Res. Commun. 16:113-115.

Kathabwalika, D.M., E.H.C. Chilembwe, V.M. Mwale, D. Kambewa, J.P. Njoloma. 2013. Plant growth and yield stability of orange fleshed sweet potato (Ipomoea batatas) genotypes in three agro-ecological zones of Malawi. Int. Res. J. Agric. Sci. Soil Sci. 3:383-392.

Khalili, M., A. Pour-aboughadareh. 2016. Parametric and non-parametric measures for evaluation yield stability and adaptability in barley doubled haploid lines. J. Agric. Sci. Technol. 18:789-803.

Laurie, S.M., M. Booyse, M. Labuschagne, M.M. Greyling. 2015. Multienvironment performance of new orangefleshed sweetpotato cultivars in South Africa. Crop Sci. 55:1585-1595.

Lestari, S.U., I.H. Ricky. 2015. Dual-purpose assessment for sweetpotato. AGRIVITA J. Agric. Sci. 37:123-129.

Mau, Y.S., A.S.S. Ndiwa, I.G.B. Adwita Arsa, S.S. Oematan. 2013. Growth and yield stability of sweet potato clones across four locations in East Nusa Tenggara. AGRIVITA J. Agric. Sci. 35:95-102.

Maulana, H., S. Dewayani, M.A. Solihin, M. Arifin, S. Amien, A. Karuniawan. 2020. Yield stability dataset of new orange fleshed genotypes in West Java, Indonesia. Data Br. 32: 106297.

Maulana, H., D.M. Nugroho, L. Trimo, A. Karuniawan. 2016. Participatory selection of sweet potato based on farmers preferences in Banjar city. Proceedings of SABRAO $13^{\text {th }}$ Congress and International Congress. IPB Press, Bogor, 14-16 September 2015.

Maulana, H., H. Prayudha, Y.L. Filio, R. Suci Mulyani, D. Ustari, S. Dewayani, E. Solihin, A. Karuniawan. 2018. Variabilitas genetik F1 orange fleshed sweet potato (OFSP) asal Peru di Jatinangor berdasarkan karakter agromorfologi. Zuriat 29:88-94. 
Mohammadi, R., A. Amri. 2008. Comparison of parametric and non-parametric methods for selecting stable and adapted durum wheat genotypes in variable environments. Euphytica 159:419-432.

Mustamu, Y.A., K. Tjintokohadi, W.J. Gruneberg, A. Karuniawan, D. Ruswandi. 2018. Selection of superior genotype of sweet-potato in Indonesia based on stability and adaptability. Chil. J. Agric. Res. 78:461-469.

Ngailo, S., H. Shimelis, J. Sibiya, K. Mtunda, J. Mashilo. 2019. Genotype-by-environment interaction of newly-developed sweet potato genotypes for storage root yield, yield-related traits and resistance to sweet potato virus disease. Heliyon 5:1-23.

Oliveira, E.J. de, J.P.X. de Freitas, O.N. de Jesus. 2014. AMMI analysis of the adaptability and yield stability of yellow passion fruit varieties. Sci. Agric. 7:139145 .

Opafola, O., D. Adekunle, N. Lawal, A.A. Babalola. 2018. Estimation of water needs of sweet potato (Ipomea batatas) using the penman-monteith model in Abeokuta, Southwestern Nigeria. Arid Zo. J. Eng. Technol. Environ. 14:143-152.

Petersen, R.G. 1994. Agricultural field experiments : design and analysis. Marcel dekker inc, New York,USA.

Plaisted, R.L. 1960. A shorter method for evaluating the ability of selections to yield consistently over locations. Am. Potato J. 37:166-172.

Plaisted, R.L., L.C. Peterson. 1959. A technique for evaluating the ability of selection to yield consistently in different locations or seasons. Am. Potato J. 36: 381-385.

Pour-aboughadareh, A., M. Yousefian, H. Moradkhani, P. Poczai, K.H.M. Siddique. 2019. STABILITYSOFT : A new online program to calculate parametric and non-parametric stability statistics for crop traits. Apllications Plant Sci. 7:1-6.

Prayudha, H.N., A.M. Noerrizki, H. Maulana, D. Ustari, N. Rostini, A. Karuniawan. 2019. Keragaman genetik klon ubi jalar ungu berdasarkan karakter morfologi dan agronomi. Bul. Palawija 17:94-101.

Purchase, J.L., H. Hatting, C.S. van Deventer. 2000. Genotype $\times$ environment interaction of winter wheat ( Triticum aestivum L .) in South Africa: II. Stability analysis of yield performance. South African J. Plant Soil 17:101-107.

Purwokurniawan, B.S. Purwoko, D. Wirnas, I.S. Dewi. 2014. Potensi dan stabilitas hasil, serta adaptabilitas galur-galur padi gogo tipe baru hasil kultur antera. J. Agron. Indonesia 42:9-16.

Rad, M.R.N., M.A. Kadir, M.Y. Rafii, H.Z.E. Jaafar, M.R. Naghavi, F. Ahmadi. 2013. Genotype $\times$ environment interaction by AMMI and GGE biplot analysis in three consecutive generations of wheat (Triticum aestivum) under normal and drought stress conditions. Aust. J. Crop Sci. 7:956-961.

Rukundo, P., H. Shimelis, M. Laing, D. Gahakwa. 2017. Combining ability, maternal effects, and heritability of drought tolerance, yield and yield components in sweetpotato. Front. Plant Sci. 7:1-14.

Ruswandi, D., Y. Yuwariah, M. Ariyanti, M. Syafii, A. Nuraini. 2020. Stability and adaptability of yield among earliness sweet corn hybrids in West Java, Indonesia. Int. J. Agron. 2020:1-9.

Sabaghnia, N., M. Mohammadi, R. Karimizadeh. 2013. Parameters of AMMI model for yield stability analysis in durum wheat. Agric. Conseptus Sci. 78:119-124.

Shukla, G.K. 1972. Some statistical aspects of partitioning genotype-environmental components of variability. Heredity 29:237-245.

Solihin, M.A., R.P. Santun, S.R.P. Sitorus, A. Sutandi, Widiatmaka.2018. Discriminating land characteristics of yield and total sugar content classes of cilembu sweet potato (Ipomoea batatas L.). AGRIVITA J. Agric. Sci. 40:15-24.

Sunyoto, M., R. Andoyo, E. Masitoh. 2019. Characteristics of high protein snackbar made of modified sweet potato flour. Int. J. Adv. Sci. Eng. Inf. Technol. 9:422-427.

Thennarasu, K. 1995. On certain non-parametric procedures for studying genotype-environment interactions and yield stability. Disertasi. PJ School, IARI, New Delhi, India, IN.

Vaezi, B., A. Pour-Aboughadareh, A. Mehraban, T. HosseinPour, R. Mohammadi, M. Armion, M. Dorri. 2017. The use of parametric and non-parametric measures for selecting stable and adapted barley lines. Arch. Agron. Soil Sci. 64:597-611. 
Vaezi, B., A. Pour-Aboughadareh, R. Mohammadi, A. Mehraban, T. Pour-Hossein, E. Koohkan, S. Ghasemi, H. Moradkhani, K.H.M. Siddique. 2019. Integrating different stability models to investigate genotype $\mathrm{x}$ environment interactions and identify stable and high-yielding barley genotypes. Euphytica 5:1-18.

Waluyo, B., A.A. Roosda, N. Istifadah, D. Ruswandi, A. Karuniawan. 2015. Identification of fifty sweetpotato (Ipomoea batatas (L.) Lam.) promising clones for bioethanol raw materials. Energy Procedia 65:22-28.

Wricke, G. 1962. Übereine Methode zur Erfassung der ökologischen Streubreite in Feldversuchen. Zeitschrift für Pflanzenzüchtung 47:92-96.

Xu, N.Y., F. Michel, Z. Guo-wei, L. Jian, Z. Zhi-guo. 2014. The application of GGE biplot analysis for evaluating test locations and mega-environment investigation of cotton regional trials. J. Integr. Agric. 13:1921-1933.

Yan, W., N.A. Tinker. 2006. Biplot analysis of multienvironment trial data: Principles and applications. Can. J. Plant Sci. 86:623-645.

You, F.M., S.D. Duguid, D. Thambugala, S. Cloutier. 2013. Statistical analysis and field evaluation of the type 2 modified augmented design (MAD) in phenotyping of flax (Linum usitatissimum) germplasms in multiple environments. Aust. J. Crop Sci. 7:1789-1800.

Zhang, P.P., H. Song, X.W. Ke, X.J. Jin, L.H. Yin, Y. Liu, Y. Qu, W. Su, N.J. Feng, D.F. Zheng, B.L. Feng. 2016. GGE biplot analysis of yield stability and test location representativeness in proso millet (Panicum miliaceum L.) genotypes. J. Integr. Agric. 15:12181227. 